\title{
Influence of social networks on the therapeutic itineraries of people with venous ulcer
}

\author{
Influência das redes sociais no itinerário terapêutico de \\ pessoas acometidas por úlcera venosa \\ Influencia de las redes sociales en itinerario terapéutico \\ de personas afectados por úlcera venosa
}

\author{
Dalva Cezar da Silva \\ Maria de Lourdes Denardin Budób \\ Maria Denise Schimith ${ }^{c}$ \\ Gilson de Vasconcelos Torres ${ }^{\mathrm{d}}$ \\ Vânia Lúcia Durgante ${ }^{\mathrm{e}}$ \\ Salete de Jesus Souza Rizzattif \\ Bruna Sodré Simon ${ }^{9}$
}

\begin{abstract}
The aim of this study was to identify the influence of social networks in the therapeutic itinerary of people affected by venous ulcers. Qualititative research was conducted in the outpatient clinic of a public hospital in Rio Grande do Sul, Brazil. Data were collected from January to February 2013 by means of semi-structured interviews with 14 people affected by venous ulcers. Content analysis provided the following categories: The family worries with me; I get lots of help from friends and neighbours, and I do it myself. Results revealed some elements of social networks that influence choices and continuity of treatment and care of patient with venous ulcers. It is therefore necessary for nurses to familiarize themselves with these social networks and work with them to strengthen the partnership in care.
\end{abstract}

Descriptors: Social support. Varicose ulcer. Nursing.

\section{RESUMO}

Objetivou-se conhecer a influência das redes sociais no itinerário terapêutico de pessoas acometidas por úlcera venosa. Pesquisa qualitativa, realizada no ambulatório de um hospital público do interior do Rio Grande do Sul, Brasil. Coleta de informações de janeiro a fevereiro de 2013, com entrevista semiestruturada, da qual participaram 14 pessoas acometidas por úlcera venosa. Empregou-se a análise de conteúdo, construindo-se as categorias: A família se preocupa junto; Tive muita ajuda de amigos e vizinhos e Eu mesmo faço. Os resultados permitiram conhecer elementos das redes sociais que influenciam nas escolhas e continuidade dos tratamentos e cuidados da pessoa acometida por úlcera venosa. Aponta-se a necessidade da enfermagem conhecer essa rede social e atuar junto a ela para fortalecer a parceria no cuidado.

Descritores: Apoio social. Úlcera varicosa. Enfermagem.

\section{RESUMEN}

El objetivo fue conocer la influencia de redes sociales en el itinerario terapéutico de personas afectados por úlceras venosas. Investigación cualitativa llevada en consulta externa de un hospital público de Rio Grande do Sul, Brasil. La recolección de información fue de enero a febrero de 2013, con entrevista semiestructurada donde participaron 14 personas afectados por úlceras venosas. Se aplicó el análisis de contenido, construyéndose las categorías: La familia se preocupa junto; Yo tuve la ayuda de amigos y vecinos; Yo mismo lo hice. Los resultados nos han permitido conocer los elementos de las redes sociales que influyen en las decisiones y continuidad del tratamiento y cuidado de las personas afectado por úlcera venosa. Se señala la necesidad de enfermería para conocer esa red social y trabajo junto con ella para reforzar la colaboración en el cuidado.

Descriptores: Apoyo social. Úlcera varicosa. Enfermería.
DOl: $\quad$ http://dx.doi.org/10.1590/1983-

1447.2014.03.45072

\footnotetext{
Nurse. Doctoral-degree student of nursing at the Federal University of Rio Grande do Norte (UFRN). Santa Maria, RS, Brazil.

${ }^{b}$ Nurse. Phd in nursing. Associate professor $\|$ of the department of nursing and the Graduate Nursing Programme (PPGEnf) at the Federal University of Santa Maria (UFSM). Santa Maria, RS, Brazil.

'Nurse. PhD in Sciences. Adjunct Professor I of the department of nursing and the PPGEnf/UFSM. Santa Maria, RS, Brazil.

d Post-doctoral degree in nursing - Évora/Portugal. $\mathrm{PhD}$ in Nursing. Full Professor of the UFRN. Scholarship of Productivity in Research PQ2/CNPq. Natal, RN, Brazil.

e Nurse. Master's degree in nursing. Santa Maria, RS, Brazil.

N Nurse. Master's degree student of the PPGEnf/ UFSM. Santa Maria, RS, Brazil.

${ }^{9}$ Nurse. Master's degree in nursing. Substitute Professor of the department of nursing at the UFSM. Santa Maria, RS, Brazil.
} 


\section{口INTRODUCTION}

The course that patients complete in search of treatmentand a curefor diseases is called therapeutic itinerary ${ }^{(1)}$. During this itinerary, many of these patients are influenced when making decisions on care and treatment. This influence may come from family members, neighbours, friends, members of the community and, especially, from those who have somehow experienced the condition of sickness ${ }^{(1)}$.

The sum of all these relationships that patients perceive as important, either due to bonds with family, friends or people they know, are characterized as personal social network ${ }^{(2)}$. This social circle based on affinity forms a sort of web that unites people, and can be modified in time and with changes that occur in life ${ }^{(2)}$.

Functions of the social network are mainly social company, emotional support, cognitive guide and advice, social regulation or control, material help and services, and access to new contacts ${ }^{(2)}$. Consequently, it contributes to healthcare habits and the capacity to adapt in a crisis $^{(2)}$, and becomes the support that can be used in situations of sickness ${ }^{(3)}$. For healthcare professionals, it is important to know the social network to diminish possible negative effects related to the excessive burden of care ${ }^{(3)}$.

In the case of patients with venous ulcer, there are usually changes to daily activities due to the presence of pain, mobility limitations, sleep disorders, changes to self-image and difficulties in working. There may also be a financial impact, as monthly income tends to decrease and costs on treatment tend to increase ${ }^{(4-5)}$

The intervention of nursing extends further than the mere wound when evaluation and treatment focus on the patient as a complex and integral being ${ }^{(6)}$. This emphasizes the importance of support provided by individuals in a similar situation who participate in self-help groups or support provided by nurses ${ }^{(6)}$.

For this reason, the proposed question is: How does the social network influence the therapeutic itinerary of patients with venous ulcers? The aim of this question was to identify the influence of social networks in the therapeutic itinerary of people with venous ulcer.

\section{METHOD}

The adopted method for this study was qualitative research, based on a master's dissertation ${ }^{(7)}$, and conducted in the outpatient unit of a public hospital in the interior of Rio Grande do Sul, Brazil.
Research included patient diagnosed with venous ulcer, over the age of 18 and receiving treatment at the outpatient angiology unit, which provides exemplary services to 44 municipalities of the $4^{\text {th }}$ and $10^{\text {th }}$ Coordination Department of Health.

A total of 14 individuals participated in semi-structured interviews between January and February 2013. The interviews were recorded, transcribed and studied using the content analysis method proposed by Bardin ${ }^{(8)}$, considering three pre-analysis stages; exploration of material and treatment of results, inference and interpretation.

Research was registered by the Ethics Committee of the university connected to the project, under number 23081.000145/2008-19, with observance of ethical precepts of research on human beings. Results were presented using code $E$ followed by the number of the order in which interviews were conducted.

\section{RESULTS AND DISCUSSION}

Of the 14 people interviewed, nine were women and five were men. Ages ranged from 47 to 79 years, being that nine individuals were more than 60 years old. Time of existence of the ulcer varied between six months and 25 years. Relapses were reported by ten patients, and for four patients, it was the first time they had had venous ulcer. Also, 13 patients had an ulcer and one patient had two ulcers, one in each lower limb.

Most of the interviewees lived with their children and spouses, and some also lived with their grandchildren. Three lived alone and had greater contact with neighbours as their family members lived in other cities.

Analysis allowed the creation of the following categories: My family worries with me; I get lots of help from friends and neighbours and I do it myself.

\section{My family worries with me}

In the therapeutic itinerary of people with venous ulcer, there was extensive positive influence from the family. Family members provided or helped to provide first-aid care at home, such as dressing or enabling moments of rest. Furthermore, they had some control over care and aid in terms of obtaining assistance from the healthcare professional.

When patients need help and seek support during sickness, they usually resort to family members first, as this helps to reduce possible negative effects related to caring for a family member with a chronic health condition ${ }^{(3)}$. 
The family is mentioned as being the main source of help in sickness, and is responsible for direct and indirect care.

My family worries with me [...]. My wife always helps, getting material for me, and if necessary, she helps me dress the wound [...]. If I need extra support, my son and daughter-in-law also help (E3).

My kid [daughter] used to help. Now my grand-daughter helps [with the dressing] and with the boot [Unna], I only change this outside part. My grand-daughter helps me, she is 14 years old (E5).

My daughter is "my nurse" [who helps with the care]. My son, who lives next door, carries me if I go out and comes with me, sometimes he helps with the dressing (E11).

Family members who help are the closest relations, such as wife, son or daughter, daughter-in-law or grand-daughter. This help can include dressing wounds at home and seeking healthcare services.

Material help is characterized as one of the functions of a network ${ }^{(2)}$. There is a predominance of women helping with care, being that they are generally the people called for when care is required in the family network. This reinforces the cultural practice of resorting to the female gender as the main provider of care, which can be shared to reduce overload of these women during care ${ }^{(9)}$. Similarly to the studied group, family members have been identified as showing concern for care, and children were mentioned as carers of people with venous ulcer ${ }^{(10)}$.

Statements also showed that family members enabled time for rest.

My daughter-in-law comes home, she helps, washes clothes, does lots of things and does not let me do any housework. So, I sit down, with my foot up and that resting time helps me, it doesn't hurt (E5).

Now I have my [daughter] who is 16 years old and she helps out, but before that it was just me. Serious rest, I can do that now, take a few minutes to lie down, lift my leg (E1).

The family influences by helping with daily chores and providing moments of rest. This and the time to lift lower limbs improve venous return, which reduces the oedema and favours the healing process of the ulcer. Thus, it is important to know which resources are made available for care and how patients live ${ }^{(11)}$.
In addition to helping with the care, family members also exert "control" in relation to the activities of the person with venous ulcer. Ulcers can cause incapacity and distance sufferers from daily activities and leisure, which leads to a negative interference on the quality of living of these individuals ${ }^{(10)}$.

They [family members] are always trying to help and provide comfort so I can move about and they help in any way they can so I don't have to walk too much, a child's life [laughter] (E3).

My mother and sisters say: "be careful, don't go near the dirt, don't go here, don't go there" (E6).

This overprotection can be compared to "living like a child"that is monitored and controlled by the family. Family care tends to protect and impose rules, which can interfere with the autonomy of people with venous ulcer and during the search for care by encouraging or repressing some practices.

In this sense, as a function of social regulation, overprotection of the network neutralizes "behaviour deviations"(2), rules and values that stray from collective expectations. Care circulates among generations and renovates and strengthens bonds, as it is connected to previously established relationships between family members ${ }^{(12)}$.

Family also influences in the search for assistance from the healthcare professional, stimulates the search and is responsible for choosing this professional.

It took me a while to look for a doctor because I was stupid, I didn't want to go, and that was when they [family members] convinced me to go (E11).

The search for a healthcare professional is mostly initiated due to the influence of family members, who usually accompany the patient to consultations or participate in care and treatment. It is therefore family members who indicate or suggest which professional (doctor) is ideal to continue with treatment.

I went to a specialist on varicose veins, my daughter-in-law took me (E4).

I got home and said, "I'm going to choose a specialist," and then my sisters told me let's get the same doctor that's treating dad (E6).

When patients choose to seek professional help for the disease, they consult their family to evaluate and decide 
what to do with the prescribed treatment. In this way, patients plan and organize individual acts and subsequently evaluate whether care was effective and whether the expected results were obtained ${ }^{(13)}$.

The family is also influenced by knowledge provided by the healthcare team, especially nurses.

My companion, dressed [the wound]. The nurses told her how to do it (E8).

Guidelines provided by nurses favour and promote care, and prepare the family to confront the situation caused by the emergence of a disease. In this case, the role of nurses during planning of an intervention proposal that considers the patient and the family group when providing care for ulcers favours adhesion and continuity of the proposed treatment ${ }^{(5)}$.

Information can also occur by means of contact with family members who have suffered from venous ulcer.

Always making medicine, as I saw my mother do, I was used to it, because I was brought up watching my mum with that thing on her leg, and she had it for almost 40 years (E12).

The more experienced family members can influence in practices related to the treatment of wounds, as they transmit their knowledge to other generations ${ }^{(14)}$. Statements reveal the cultural influence on care, based on respecting and valuing the knowledge of people who transfer their knowledge on the cause of diseases and their treatment ${ }^{(3)}$.

Other means of communication such as internet ${ }^{(15)}$ and books are sources of information on healthcare. However, healthcare professionals and family members have the greatest influence on the decision-making process of care $^{(16)}$, and may favour adhesion to treatment ${ }^{(17)}$.

Furthermore, the emotional support provided by the family boosts the effectiveness of treatment and the feeling of hope in the improvement of health.

I think about getting better and living with my children, they are all good, if I need them, all I have to do is call. One thing that amazes me is their support and kindness, even my tiny grand-son worries about me (E11).

Support is identified as favourable for emotional equilibrium. It is configured as non-professional care and can reduce the hazardous effect of structural needs. It is also considered a source of protection and emo- tional support ${ }^{(18)}$. However, in some situations, discrimination of the family and the absence of support during treatment can have a negative effect and contribute to chronicity of the ulcer ${ }^{(4)}$.

\section{I get lots of help from friends and neighbours}

Friends can favour care practices and influence the therapeutic itinerary of people with venous ulcer.

The actual relationship with the healthcare team is considered a "friendship/kinship," which is represented by the good relationship and bond that is maintained during follow-up at the outpatient unit. This occurs due to the extended duration of treatment that patients receive.

We [interviewee and another patient that is receiving treatment at the outpatient unit] agreed that the day we get better, we are going to take a picture with you here. We're going to miss the nurses, the conversations. It's like being a relative. It's like a brotherhood, loving and respecting each other (E2).

Statements reveal the importance of bonding with the people who accompany their treatment at the outpatient unit. Patients want to recovery from their ulcer, but they do not want to lose the relationship and bond with the service and the professionals who provide care.

Contact with friends and other people who have suffered similar experiences and also wait for care at the unit can favour the exchanging of experiences and the sharing of emotional support offered by family members. Moreover, it enables the passing of time, conversations and dealing with the demands of treatment. People who have experienced or are experiencing similar situations are also considered sources of information ${ }^{(3)}$.

Nurses must value the social network represented by friendship bonds as a strategy for effective care that focuses on improving quality of life, both in the physical and psychological sense ${ }^{(19)}$.

For the interviewees who got help from neighbours and friends, this type of support was represented by emotional support, with the addition of material support and services.

I got lots of help from friend and neighbours, both emotional and psychological. They helped by visiting to know how I was, offering motivation, to reduce the despair and not allow depression to set in, and help my wife with the work (E3). 
Statements also revealed feelings of solidarity between members of the friendship network in difficult situations or sickness, a time in which help to provide care is offered. This help influences the conformation of the search for care.

Friendship bonds with neighbours are important and beneficial insofar as they allow support when any form of help or assistance is required ${ }^{(19)}$.

Analysis of therapeutic itineraries of families with members that suffered from high blood pressure showed that help with the housework and the support of neighbours and friends were fundamental for the success of treatment. Participation of the network was required when family members did not know or were unsure about decisions that had to be made concerning care of their family member ${ }^{(20)}$.

After the family, friends and neighbour are referred to as the most important members of the relationship network. This shows the importance of healthcare professionals knowing and valuing these friendship networks, considering they may be a strategy for providing sensitive assistance $^{(19)}$.

Getting to know the social network is important because it is generally set in motion during moments of difficulties, such as periods of illness. The activation of various segments of the social network may favour adhesion to treatment and quality of life ${ }^{(3,19)}$.

Furthermore, the social network influenced the therapeutic itinerary of interviewees with venous ulcer in relation to choosing treatment, searching for resources to establish a given care practice, whether popular or professional. In this study, neighbours and friends were responsible for indicating other therapies, such as teas, medicinal plants or cleaning products for the ulcer.

The use of these practices is generally based on experiences acquired by means of success obtained when used by other people of the relationship network ${ }^{(1)}$. When treating wounds, it is important for the plants used to have confirmed action to prevent further harm ${ }^{(14)}$.

Neighbours can help in the search for a healthcare service or transport, and favour the continuity of assistance when scheduling consultations and tests.

I'm grateful to my neighbour who helped me so much, he brought me here for the first time for a consultation, he was the one who scheduled the tests the first time. It was all my neighbour's doing, he helped me because my legs were really bad (E10).
Friends also play an active role in relation to transporting patients. This social network becomes a form of confronting the adversities of life ${ }^{(19)}$.

Geographical distances in relation to the healthcare service can be minimized by having an organized and effective social network. In this context, healthcare professionals should pay attention to situations in which there are limitations of the social network, and seek resources that can meet the transportation needs of people with venous ulcer.

Other important issues are referral and counter-referral, the need of approximation with Primary Care and of making home visits, as a strategy to allow and stimulate the continuity of care.

\section{I do it myself}

The therapeutic itinerary of people with venous ulcer is still influenced by the situation in which the social network is reduced or not used.

The lack of support was sometimes mentioned by interviewees who lived alone.

No one helps me do it [dressing]. My kids are all married, they live in the capital. My old lady used to do it [deceased wife] (E2).

For some people, the lack of help is due to absence or distance of family members, which hinders or prevents care procedures with ulcers. It should be noted that in addition to the clinical treatment, nurses must also plan care actions based on individual characteristics and thus provide guidelines to enable the patient's understanding of the health condition and promote better adaptation ${ }^{(4)}$.

Social networks can be weakened at some moments. During chronic disease and the consequently prolonged treatment, this network is usually reduced, many times due to the impossibility of daily contact with people ${ }^{(2)}$.

On the other hand, even with the help of family or neighbours, interviewees revealed the desire to be responsible for their care, not characterizing loneliness or abandonment. Some patients never needed to ask for the help of friends or neighbours.

I do it [dressing] myself because I don't like to bother people (E10).

I do the dressing myself, I don't like others doing it because it's more painful (E9). 
Not requesting help may be related to shame of showing the ulcer or not wanting to overload people who offer their help. Another cause can be the perception of being able to complete the procedure without help, thus revealing autonomy.

There were some difficulties in maintaining care at home, which is when these patients sought help at the healthcare service to continue with care.

I was always the one who took care of it. If I didn't go to the unit, I did it myself (E4).

I get the dressing material from the healthcare unit. I dress the wound at home, I change it myself (E10).

In situations of illness, when there is no family network, other sources are incorporated, such as healthcare professionals. Consequently, this help can also influence choices during the search for treatment. This is related to the practice of professionals who provide information on care ${ }^{(3)}$.

When the social network is stable, active and reliable, it functions by aiding and referring to healthcare services ${ }^{(2)}$. However, this network is not always used, so nurses must be aware of people who need help as they can be the ones who are most in need of professional care.

\section{CONCLUSION}

The influence of social networks can facilitate adoption of several forms of care and its conformation can modify the therapeutic itinerary. The importance of a consistent and positive network represented by family, neighbours, friends and healthcare professionals was identified.

Home care is possible with help from the family, which has become an ally of the therapeutic process, especially in terms of dressing wounds or enabling moments of rest. Moreover, it favours adhesion to treatment by offering emotional support, encouraging care practices and helping to transport sufferers to the healthcare services. The presence of an organized and active social network can favour continuity of treatment at the healthcare service, although it was identified that this network is not always set in motion.

Results showed that nurses should familiarize themselves with the social network and work with it to strengthen the care partnership. The role of nurses during planning of care together with the social network is therefore important for the development of comprehensive care to people suffering from venous ulcers.
Nursing care, and the care of other healthcare professionals, can benefit from becoming familiar with the social network of people with venous ulcer. This, therefore, suggests the conduction of other studies on this subject, considering that this study was limited to a single scenario, namely an outpatient unit.

\section{REFERENCES}

1. Mattosinho MMS, Silva DMGV. Itinerário terapêutico do adolescente com diabetes mellitus tipo I e seus familiares. Rev Latino-am Enferm. 2007;15(6):1113-9.

2. Sluzki CE. A rede social na prática sistêmica. 3. ed. São Paulo: Casa do psicólogo;2006.

3. Silveira CL, Budó MLD, Ressel LB, Oliveira SG, Simon BS. Apoio social como possibilidade de sobrevivência: percepção de cuidadores familiares em uma comunidade remanescente de quilombos. Ciênc Cuid Saúde. 2011;10(3):585-92.

4. Costa IKF, Nóbrega WG, Costa IKF, Torres GV, Lira ALBC, Tourinho FSV, et al. Pessoas com úlceras venosas: estudo do modo psicossocial do modelo adaptativo de Roy. Rev Gaúcha Enferm. 2011;32(3):561-8.

5. Angélico RC P, Oliveira AKA, Silva DDN, Vasconcelos QLDQ, Costa I KF, Torres GV. Socio-demographic profile, clinical and health of people with venous ulcers treated at a university hospital. J Nurs UFPE on line [Internet]. Available in: http://www.ufpe.br/revistaenfermagem/index.php/revista/article/ view/2100/pdf_759.

6. Fonseca C, Franco T, Ramos A, Silva C. A pessoa com úlcera de perna, intervenção estruturada dos cuidados de enfermagem: revisão sistemática da literatura. Rev Esc Enferm USP. 2012;46(2):480-6.

7. Silva $D C$. Itinerário terapêutico de pessoas com úlcera venosa em assistência ambulatorial: contribuiç̧ôes à enfermagem[dissertação]. Santa Maria (RS): Universidade Federal de Santa Maria; 2013.

8. Bardin L. Análise de conteúdo. São Paulo: Ediç̧ões 70; 2011.

9. Budó MLD, Resta DG, Denardin JM, Ressel LB, Borges ZN. Práticas de cuidado em relação à dor: a cultura e as alternativas populares. Esc Anna Nery. 2008;12(1):90-6.

10. Nottingham IC, Victor JF, Brito CKD, Feitoza SMS, Monteiro LS, Balbino AC. Assessment of biopsychosocial aspects of patients with venous ulcers. J Nurs UFPE on line [Internet]. 2012. Available in: http://www.ufpe.br/revistaenfermagem/ index.php/revista/article/download/2927/4047.

11. Budó MLD, Oliveira SG, Garcia RP, Simon BS, Schimith MD, Mattioni FC. Redes sociais e participação em uma comunidade referenciada a uma unidade de saúde da família. Rev Gaúcha Enferm. 2010;31(4):753-60.

12. Flores GC, Borges ZN, Budó MLD, Silva FM. A dádiva do cuidado: estudo qualitativo sobre o cuidado intergeracional com o idoso. Ciênc Cuid Saúde. 2011;10(3):533-40.

13. Kleinman A. Patients and healers in the context of culture. Berkley: University of California; 1980.

14. Alcoforado CLGC, Santo FHE. Saberes e práticas dos clientes com feridas: um estudo de caso no município de Cruzeiro do Sul, Acre. Reme: Rev. Min. Enferm. 2012;16(1):11-7.

15. Read J, Kinali M, Muntoni F, Weaver T, Garralda ME. Siblings of young people with duchenne muscular dystrophy e a qualitative study of impact and coping. Eur J Paediatric Neurol. 2011;15(1):21-8.

16. Amaral RFC, Souza T, Melo TAP, Ramos FRS. Itinerário terapêutico no cuiddado mãe-filho: interfaces entre a cultura e biomedicina. Rev Rene. 2012;13(1):85-93. 
17. Azoubel R, Torres GV, Silva LWS, Gomes FV, Reis LA. Efeitos da terapia física descongestiva na cicatrização de úlceras venosas. Rev Esc Enferm USP. 2010;44(4):1085-92.

18. Tavares RS, Silva DMGV. A implicação do apoio social no viver de pessoas com hipertensão arterial. Rev Gaúcha Enferm. 2013;34(3):14-21.
19. Faquinello P, Marcon SS. Amigos e vizinhos: uma rede social ativa para adultos e idosos hipertensos. Rev Esc Enferm USP. 2011; 45(6):1345-52.

20. Trad LAB, Tavares JSC, Soares CS, Ripardo RC. Itinerários terapêuticos face à hipertensão arterial em famílias de classe popular. Cad Saúde Pública. 2010;26(4):797-806.

\section{Author's address:}

Dalva Cezar da Silva

Universidade Federal de Santa Maria

Av. Roraima, 1000, Cidade Universitária

97105-900, Santa Maria, RS

E-mail: dalvacezarsilva@yahoo.com.br
Received: 14.02.2014

Approved: 09.05.2014 